\title{
Traversing beyond postcolonial identity: symptomatic self- annihilation in The God of Small Things as a symbolic failure in Roy's politics
}

\author{
Krishanthi Anandawansa ${ }^{1 *}$ and Mahesh Hapugoda ${ }^{2}$ \\ ${ }^{I}$ Department of Languages, Faculty of Management, Social Sciences and Humanities, General Sir John Kotelawala Defence University, \\ Ratmalana, Sri Lanka. \\ ${ }^{2}$ Department of Languages, Faculty of Social Sciences and Languages, Sabaragamuwa University of Sri Lanka, Belihuloya, Sri Lanka.
}

\begin{abstract}
This study claims that the roots of the symptomatic 'madness' found in the Syrian-Christian Kottayam family in The God of Small Things by Arundhati Roy traverse beyond the general postcolonial identity crisis. It investigates the selfdestructive element hidden within this family that obviously had an impact on Ammu, Chako, Baby Kochamma and others in developing some form of self-annihilation, which cannot be simply attributed to postcolonial identity politics. The authors find that the 'dual identity' (symbiosis) (Bhabha, 1994), the 'disconnectivity' (Jameson, 1991) and 'death as a pathway to rebirth' (Holbrook, 1971) experienced by the Kottayam family force the authors' reading of the novel to go beyond postcolonial discourse and exploit Žižekian psychoanalytic tools. The death drive and self-annihilation that run within the family members, which distance them from the rest of the contemporary Kerala society, demand a broad universal analysis of the text. The only rebel in The God of Small Things, Ammu, who 'radically annihilated her existence' by loving an untouchable, ends up in a tragic Žižekian misrecognition. Her act is, therefore, an attempt of escapism from the false deadlock of stagnating identity politics that made her life quite miserable and unliberating. Though there are substantial features of discursive success throughout the novel, Roy's own failure and inability to contextualise India in a universal emancipatory stream is widely evidenced by the symbolic deaths in her 'imaginary' (yet empirical) family.
\end{abstract}

Keywords: Dislocation, postcolonial identity, symptomatic self-annihilation.

\section{INTRODUCTION}

Defining post-colonialism involves various attempts to conceptualise the 'post' experience of societies subjected to the historical circumstances of imperialism. Hence, it encompasses an involuntary and critical meaning from the oppositional use of the terms 'colonial' and 'postcolonial'. Critics and their usage of the terms 'postcolonial' and 'postcolonial' have brought in further complementary and conflicting dimensions of the terms, as in when Ashcroft et al.'s The Post-Colonial Studies Reader brought together two decades of key essays (1975-1995) that contributed to the formation of the critical discourse in the matter. Ashcroft et al.'s (1995) text opted to retain the hyphen, signifying a temporal use of the term 'post'. Hence, 'post-colonial studies' for Ashcroft's colleagues seems something that took place after the phenomenon of colonialism; a problematic assumption that disregards the postcolonial tendencies of the earlier texts, as well as bringing in the presumption that colonialism is over.

In contrast, Elleke Boehmer's Colonial and Postcolonial Literature published in the same year (1995), removes the hyphen and inserts the term 'literature' instead of 'studies', raising questions to actually what is the ultimatum of postcolonialism's critique. Postcolonialism can be said to have first found voice as a form of literary analysis through the essential work of Edward Said's Orientalism (1978) and his later work of Culture and Imperialism (1993). These evidences have come to show the importance of the subject matter and field of theoretical insight that has spread in vast to bridging disciplinary divides, while at the same time blurring them. The subject 'postcolonial' and its phenomenon thus developed and critics have taken over the spread of its dialectics as in when Aijaz Ahmad quotes that "any resistance to colonialism is always, already postcolonial” (Ahmad, 1997; pp: 336337), highlighting the merging and interpretations of both temporal and phenomenal aspects. 
The phenomenal growth of 'post-colonialism' or 'postcolonialism' as a historical fact, subject matter and subjective involvement as explained above, and the various criticisms, theories and writings generated in the aftermath of British colonialism in Asia, Africa and Pacific regions lead one to understand that far from being over, postcolonialism is still a site of struggle and is a vast theoretical discursive premise in commonwealth cultures, such as India and Sri Lanka, in an aftermath of even 70 years of post-independence. In other words, the 'colonial project' (Žižek, 2013) is not over and has left a permanent mark.

Amidst the 'crisis' above, and in a context where postcolonial nations are gradually working towards reaching 'developed' status, issues such as nationhood, ethnic harmony/unrest, migration, political/religious exile, identity, cultural diversity and the 'colonialist mentality' (Ashcroft etal., 1995) remain matters of serious inquiry. This is where the 'native intellectual' (Fanon, 1963) needs to play an important role. As Fanon suggests, the 'native intellectual' is a leader among the colonised, whose mind has been colonised by the oppressor through Western education, often through European institutions (Fanon, 1963). Fanon further expresses that the 'native writer' goes through three phases that characterise the evolution of the 'native intellectual'; the first phase being the proof "that he has assimilated the culture of the occupying power" (Fanon, 1963), and his inspiration is European, and that it is possible to link the works with definite trends in the literature of the mother country (Fanon, 1963). In the second phase, "the native is disturbed" (Fanon, 1963); he tries to recall origins, past happenings, and reflects on old legends "in the light of a borrowed estheticism" (Fanon, 1963). In the final phase, "the native...will shake the people...hence comes a fighting literature, a revolutionary literature, and a national literature" (Fanon, 1963).

It is within this context that the role of the 'native intellectual' as a writer who 'documents' the postcolonial comes in as social responsibility, and it is within this light that postcolonial writers who write in this 'situation', such as Chinua Achebe, Ngugi wa Thiong'o, V. S. Naipaul, Arundhati Roy, Salman Rushdie, Shyam Selvadurai, Carl Muller and Michael Ondaatje, amongst many other, deem significant. The diverseness of themes engrossed in these works range from references to war, education, conflicting demands of culture, expectations of independence, colonialism and its disillusionment to issues and atrocities in the larger geo-political climate, to name a few.

How is it possible to single out Arundhati Roy in this debate and discussion of the 'native intellectual's
(Fanon, 1963) 'colonialist mentality'? (Ashcroft et al., 1995). What is so unique about her writing in terms of 'postcolonial identity' and its politics? To answer these questions, one needs to investigate, at least in brief here, the author's background, her nuances, (dis) position as a 'native intellectual' (Fanon, 1963) and the (dis)advantages of being simultaneously an 'insider' vs. 'outsider' (Bishop, 1992).

Roy was born in one of the smallest states in India (Shillong) to a Keralite Syrian Christian mother (teacher and activist, from whom Roy inherits the latter traits of activism) and a Bengali Hindu father (tea planter). Her childhood was spent in Aymanam in Kerala, schooling in Corpus Christi, a Christian school in Kerala. Later on, she leaves Kerala for Delhi at the age of 16, and embarks on a homeless lifestyle, staying in a small hut with a tin roof, and making a living selling empty bottles. She then proceeds to study architecture at the Delhi School of Architecture, where she meets her first husband.

Roy's biography instantaneously calls attention to the stark similarities in the foundations and characterisation of the novel The God of Small Things: the plot involving a Syrian Christian family in Kerala, living in the fictitious Ayemenem, surrounded by a dominant Hindu, caste enshrined society in both the near and broader context. The immediate resonance is the marginal position of the Syrian Christians in a dominant Hindu culture, and the isolation, fear, non-homogenous affiliations that it creates in the social sphere, not forgetting the 'experiment' in language Roy creates in the novel, possibly resonating from the author's architectural inclination towards an interest in form and structure. All this makes Roy's work unique amidst other Indian writers, in addition to the fact that she continues to live in India, unlike other renowned Indian authors, i.e., Naipaul and Rushdie, and her writing reflects the engagements and traumas of the postcolonial subject with a clear 'insider-outsider' (Bishop, 1992) perspective.

It is obligatory at this point in the introduction of this paper, to explain in brief the origins and 'position' of the Syrian Christian community in Kerala. Syrian Christians number up to around 5 million of the 30 million population in Kerala, and the tag 'Syrian' has no relationship with Syria or its nationality. The term was fixated when Syriac was incorporated as the liturgical language by a section of Kerala Christians in the $17^{\text {th }}$ Century. The community traces its history to $1^{\text {st }}$ Century CE. It is believed that the apostle St. Thomas came to Kodungalloor in Kerala in $52 \mathrm{CE}$ and converted a few Brahmin families into the Christian fold. It is also believed that he founded 7 churches in Kerala, and instituted the Brahmin converts as their priests and caretakers (Varghese, 2004). Thus 
the Syrian Christians were built into an already existing Brahmanic culture, and it is noted that this group of Syrian Christians were considered at par with the uppercaste Hindus of Kerala in nobility (John, 2007). It is also noted that the Syrian Christians were a close-knit, endogamous group (John, 2007; Fuller, 1976).

Within this context, it is important to highlight how the subject's mind is 'reconstructed' in what is termed as the 'second form of colonization', resulting in identity issues and crisis, which can also be adopted as psychological traumas and issues pertaining to the characters in The God of Small Things:

"This colonialism colonizes minds in addition to bodies and it releases forces within the colonized societies to alter their cultural priorities once and for all. In the process, it helps generalize the concept of the modern West from a geographical and temporal entity to a psychological category. The West is now everywhere, within the West and outside; in structures and in minds" (Nandy, 1983).

The contextual positions and dimensions presented above on the Syrian Christians in Kerala suggest a community within a community, and it is inevitable that issues of identity, group preservation and mentality, caste and inter-relationships exist as portrayed in, i.e. the case of Ammu and Velutha, the pivotal characters in The God of Small Things. It is within such a context that the possibility of traversing identity issues will be discussed, as the very title of this paper suggests, in the hope of finding if Roy suggests a solution for 'deviants' such as Ammu or Velutha, whose relationship only results in 'death' (metaphorically and literally).

It is obligatory to further venture into Roy's biography, for she has other unique involvements with society. To date, although Roy is known in the literary arena for her novel The God of Small Things, which has been published in 19 countries and in 16 languages (Flynn et al., 2009), if one observes her published books, articles and speeches, she is very much a human rights activist insofar as her essays, i.e., "Power Politics: The Reincarnation of Rumpelstiltskin" and "The Algebra of Infinite Justice" in Power Politics (2001) and An Ordinary Person's Guide to Empire (2004), are concerned and any critique on her novel has to bear in Roy's political interests as an activist for social justice and human rights, which has certain similar and paradoxical resonances through the portrayal of characters and their forms of resistance in The God of Small Things, which will be elaborated in detail in this paper.
When awarded the Sydney Peace Prize in 2004, Roy commented,

“...We don't have to choose between Imperialism and Terrorism, we have to choose what form of resistance will rid us of both. What shall we choose? Violence or nonviolence?... We have to choose knowing that when we are violent to our enemies, we do violence to ourselves. When we brutalize others, we brutalize ourselves. And eventually we run the risk of becoming our oppressors.” (Sydney Peace Foundation, 2017).

On the same occasion, commenting on the selection of Roy for the prize, the Director of the Peace Foundation, Professor Stuart Rees said,

"Arundhati Roy is a distinguished world citizen. She was chosen for her opposition to the violence of poverty in India and for her commitment to the global cause of peace with justice. As a writer she challenges the world. She is an outstanding communicator who writes with great clarity and grace. She insists that 'silence is indefensible', that 'Peace is not the opposite of war. Peace is the sibling of justice'. At a time of terrible disregard for human life, we need to hear from citizens like Arundhati Roy..." (Sydney Peace Foundation, 2017).

The evidence above testifies Roy's political involvement as an activist for resistance against injustice and her search for the best path towards freedom against oppression. This personal interest is reflected in The God of Small Things in the characterisation of the novel, where members of a marginal Syrian Christian family living in Ayemenem, in Kerala, in particular, face various personal and social tensions in their 'liberation' on individual and social basis, which unfortunately, only end up in a 'symptomatic deadlock' (Žižek, 1992), eventually leading to self-annihilation as this paper intends to highlight.

The question is what is Roy's proposition in the end? Does the nihilism in the novel suggest that emancipation for marginal groups is a myth in the absence of the 'Big Other' (Miller, 1993) to support a radical exit? These questions would be answered in this analysis, leading one to think of broader issues, i.e., whether emancipation is actually possible for the postcolonial subject.

The above discussion brings us to the central issue with regard to the main premise and proposition this paper holds. Roy's expedition through the lives of the Syrian Christian family in The God of Small Things develops 
beyond its postcolonial identity paradox, especially in relation to the 'madness' that is often forgotten in general literary criticism, which restricts the discourse to domains such as touchable versus untouchable and Marxist versus non-Marxist. As Roy states, there is an "unsafe edge", an "unmixable mix" (Roy, 1997) in the central character Ammu:

"What was it that gave Ammu this Unsafe Edge? This air of unpredictability? It was what she had battling inside her. An unmixable mix. The infinite tenderness of motherhood and the reckless rage of a suicide bomber. It was this that grew inside her, and eventually led her to love by night the man her children loved by day. To use by night the boat that her children used by day. The boat that Estha sat on, and Rahel found." (Roy, 1997)

The proposition extends to Chacko, the spouses of the family, twins and even to the older generation of Baby Kochamma and Mammachi. Though the individual circumstances differ, the behaviors can be detected as inherent results of psychological insecurity tinged with 'madness' that runs in the family, eventually leading to some tragic failure. Simultaneously, the 'fate' of woman (Ammu in this case) is in a backward patriarchal setting where the empty 'paternal metaphor' ${ }^{\prime 1}$ or the 'Nameof-the-Father' functions as a Master Signifier (S1) with which a community is held together (Žižek, 1992) in a rallying point of collectivity. The woman who radically desires 'freedom' from existing constructions regulated by history and tradition eventually breaking the 'father's phallic authority', would confront nothing but a presymbolic Real; a lethal destiny that annihilates existence.

In this context, this paper investigates how valuable it is to detect that the very madness in the family derives from its survival technique to 'internalize the desire' only to the Lacanian 'object-desire' within the Syrian Christian community. Those who tried to 'radicalize' the desire to the wider society either ended up in destructive failure or compensated with their lives. In this light, the position of the woman and her destiny can be brought to a level where freedom can be problematic. In other words, the depiction of woman in the Syrian Christian household in Roy's novel proves that woman cannot go 'beyond the phallus' or if she ever tries to 'go beyond her official position' (Žižek, 2011), what is opted is an inevitable death.

\section{OBJECTIVES OF THE REVIEW}

The novel would be taken as a semi-empirical, fictional narrative that proves the central Lacanian/Žižekian point mentioned in the Introduction. By means of content analysis of the novel and relevant secondary reading material, this paper theoretically explores the possible articulations of the 'madness' in The God of Small Things, providing an argumentative debate to logically validate or deny its position as a human symptom.

The main result of this research fills the critical gap in the existing literature in the analysis of Roy's novel, articulating a post-Lacanian knowledge and outlook into the analysis of The God of Small Things. Another result of the research is its attempt to push the analysis out of the context of the novel, considering it a base for articulating and understanding the symptomatic feudal development in postcolonial contexts, including that of Sri Lanka.

\section{ANALYSIS}

\section{Placing the Issue}

The very essence of The God of Small Things basically rests on the fact that the family suffers from some mysterious 'madness' that runs in almost all the characters in the Ayemenem household:

\section{“Ammu worried about madness.}

Mammachi said it ran in their family. That it came on people suddenly and caught them unawares. There was Pathil Ammai, who at the age of sixtyfive began to take her clothes off and run naked along the river, singing to the fish. There was Thampi Chachen, who searched his shit every morning with a knitting needle for a gold tooth he had swallowed years ago. And Dr Muthachen, who had to be removed from his own wedding in a sack. Would future generations say, 'There was Ammu - Ammu Ipe. Married a Bengali. Went quite mad. Died young. In a cheap lodge somewhere'.

Chacko said that the high incidence of insanity among Syrian Christians was the price they had to pay for Inbreeding. Mammachi said it wasn't." (Roy, 1997)

In her novel, Roy provides little psychoanalytical evidence for an analyst to understand 'what it is', and critics do not seem to have paid sufficient attention to find the symptoms for the family's tragic end point through which, beyond its common socio-political content, the novel promises potential for analysis in a post-colonial context. Within this proposition, the novel can be placed;

a. To understand why Ammu decides to love Velutha and why Baby Kochamma flirts with Father 
Muligan; both instances that display externalising the desire-object- that there is always a relationship between the 'desire' and the 'drive'.

b. To decode why there is a symbolic termination for the family, as far as the internalisation of the fantasy is concerned; there is always a political-ethnic factor which hinders their social evolution.

c. To evidence that radicalisation of existence, the only exit point for survival, brings an inevitable 'death' to the female subject (in this case, Ammu).

Within the context of the Indian caste hierarchy, Roy's fictitious family obviously has demarcated its own borderlines based on 'touchable-untouchable' distinctions which apparently restrict its social evolution towards modernity. This paradigm, especially in postcolonial contexts, is a pre-modern element that still requires to be more 'humanised' when a society moves into future (Habermas, 2007). Alternatively, authors believe that caste cannot be humanised and needs to be eradicated. It is a psychological/realistic bottleneck that blocks true human/emotional evolution within a particular community.

Yet, on the other hand, caste in such backward social settings simultaneously functions as a Master Signifier (S1) or a rallying point (collective entity) for the members of a community to unite. Hence, when one breaks free, it is necessary to be disobedient to a collective value that determines the totality of a community, and this is primarily distinguished on that fact whether one externalises the desire/fantasy or internalises it based on the subject's psycho-social environment and capabilities:

\section{Radical $\rightarrow$ Existenee (externalizing the fantasy) or \\ Survival $\rightarrow$ Radieal (internalizing the fantasy-object, which leads to self-annihilation)}

Figure 1: A subject's movement towards liberation

Source: Researcher's analogy

The externalisation of the fantasy, which deems it necessary to have space for an articulation of a new order, positions the subject as a radical, while the mere internalisation of it for the purpose of survival lies in contrary. Yet, both stances can be detrimental to a subject: the absence of a new symbolic order to hold the radical in his/her defiance would result in a new form of psychological and social outcaste, while the internalisation of the fantasy on the premise of mere survival in the existing symbolic order would cause psychological distress in the individual and incompatibilities with others in the community, possibly leading to 'death'. This is the crux of Roy's novel, especially in relation to Ammu and Velutha, and as the novel displays, both characters end in failure due to the said absence of an alternative symbolic order.

Let us now venture into an in-depth, and elaborative theoretical exploration of the said issues, concentrated around several thematic elements.

\section{Symbolic Space and Intersubjectiveness}

It is important, primarily, to place the characterisation of The God of Small Things within the main analytical premise addressed in this paper. Accordingly, there is a need to consider the notions of 'symbolic space' and 'intersubjectivity' (Thompson, 2005). 'Intersubjectivity' as a concept has been around for almost a century, and while its history is unclear, Husserl was apparently the first philosopher to employ the term as a fundamental facet of his philosophy, making it a cardinal principle of his philosophical method, Phenomenology. In this context of Phenomenology, 'intersubjectivity' is,

"inseparable from the concept of experience and is applicable when endeavoring to determine self's relation to others, and the relation between self's experience of others as subjects of experiences that are not directly given to self" (Thompson, 2005).

Later on Apel and Habermas reject this phenomenological premise in favour of a conception of intersubjectivity that is situated in language as an instrument of communication.

It is only in the 1950s and 1960s that the linguistic approach to intersubjectivity was popularised by Jacques Lacan, when at the same time existential psychoanalysis was at its zenith. Lacan found that language offered a more accommodating vehicle for situating intersubjectivity into the psychoanalytic conception and he also incorporated Hegel's dialectical theory of desire into the conception of intersubjectivity. Hence, the 'master-slave' Hegelian dialectic has a relationship on how the self relates to 'the other'. Also, the Lacanian 'symbolic-real-imaginary' dimension is taken into consideration in interpretation of a self's 'intersubjectivity', and the 'symbolic space' is an articulation of what Lacan indicates as a process of identification of internal self with that external image (Žižek, 1992).

If one places the situation within this Lacanian discourse of symbolic space, the intersubjective reality would possibly articulate Ammu's ultimate fate due 
to her involvements with Velutha in The God of Small Things as one that has already been carved out far in advance. The presumably higher symbolic order that prevails around the low-caste Velutha and those in the Ayemenem household state their mutual exclusiveness, and already interpellates them. This is precisely what must be transcended in the Real by radical means, going against the symbolic order, if Ammu (and many others in the novel) ought to lead contended lives.

But as the novel tragically reveals, Ammu, as well as Chacko, Baby Kochamma and the twins- Estha and Rahel- all cannot dislocate themselves from this annihilating existence and past, which is their lethal symbolic space that interpellates them as subjects with particular limitations, frailties and failures, ultimately plunging the entire clan of characters into a huge abyss of deplorable, unredeemable height. For instance as Ammu is once concerned:

"She didn't even trust the twins. She deemed them capable of anything. Anything at all. They might even steal their present back, she thought, and realized with a pang how quickly she had reverted to thinking them as though they were a single unit once again. After all those years. determined not to let the past creep up on her she altered her thought at once. She. She might steal her present back." (Roy, 1997)

For others the past is traumatic too and is internalised to a destructive end. For instance, the case of Estha:

"Once the quietness arrived, it stayed and spread in Estha. It reached out of his head and enfolded him in its swampy arms. It rocked him to the rhythm of an ancient, foetal heartbeat. It sent its stealthy, suckered tentacles inching along the insides of his skull, hoovering the knolls and dells of his memory, dislodging old sentences, whisking them off the tip of his tongue. It stripped his thoughts of the words that described them and left them pared and naked. Unspeakable. Numb. And to an observer therefore, perhaps barely there. Slowly over the years, Estha withdrew from the world. He grew accustomed to the uneasy octopus that lived inside him and squirted its inky tranquillizer on his past. Gradually the reason for his silence was hidden away, entombed somewhere deep in the soothing folds of the fact of it." (Roy, 1997)

Thematically then, as the very title of the novel hints, The God of Small Things is a masterpiece because of Roy's ability to touch the 'small things in life' and the idiosyncrasies of the characters, which ultimately reveal the traumatised behavior of victims who cannot negate from the persistent higher symbolic order, which pre-defines existence. Alternatively said, it foregrounds the Lacanian conception of the "functional role of remembering past traumas" (Žižek, 1992), which ultimately configures the realities of the characters' present behavior and determines their future too. Ironically, Roy fails to present a possible solution for her characters in the novel, which in itself should be taken as a serious issue worth of generating discourse in our times, rather than framing it as author inability.

\section{Sublimation of Symbolic Community}

The above implies that mankind heavily relies on the 'symbolic support' that holds and defines the contours of a subject in one's physical realisation in mundane existence. In so much as a subject acts in accordance to and within the limitations of this pre-determined 'symbolic space', there is no threat to one's existence. Yet, the moment a radical openness is sought beyond its contours, it marks the moment of death and sublimation. In other words, as Žižek mentions, when the subject's presence is exposed outside the symbolic community, one's being is no longer determined by a place in the symbolic network; it materialises to pure nothingness of the whole (Žižek, 1992), and the sublimity desired results in a symbolic death of the individual, who has no new locus to find support or ground.

Yet, it is this very sublimity that dialectically generates freedom from the menacles of the previous symbolic space, and calls for an articulation of a 'new discourse'. This is what precisely happens to Ammu, for her pure substance of enjoyment with Velutha, resisting the dimensions of her symbolic community, only brings her mental and physical ill health, and extermination from the Ayemenem household in the end, although there is a sense of temporary emancipation she experiences in this relationship. Hence, according to Roy's depiction, the position of woman beyond the phallic world construction is portrayed treacherous and annihilating. Yet, it could also be articulated that Ammu's very diabolic state is in itself the message of the novel and of sublime resistance; that one must engage in a radical, symbolic death which is inevitable if one seeks freedom from existing structures.

The only way out of this paradox to the next stage of social evolution is to break free from the psychological manacles (e.g. caste or skin color) of the previous era and embrace new values. Since such social mobility requires a 'radical deviation' from prevailing restrictions by means of externalising the desire to a universal level, there is a need to find the fantasy object from the wider social spectrum (away from the paternal family). This process is articulated in what Ammu does by falling in love with an untouchable, surpassing the mere survival 
technique of individuals (the mere desire of the loveobject in a given feudal context such as family or same community). However, by doing so, Ammu embraces, in Žižekian terms, a traumatic 'radical death'2 which eventually "nullifies the ideological foundation" (Žižek, 1992) of the symbolic order of the existing masculine domain. Ironically, the existing structure has by then curtailed the lives of all characters involved:

\section{"Baby Kochamma would say it is a Small Price to Pay.}

Was it?

Two lives. Two children’s childhoods.

And a history lesson for future offenders.

Clouded eyes held clouded eyes in a steady gaze and a luminous woman opened herself to a luminous man. She was as wide and deep as a river in spate. He sailed on her waters..." (Roy, 1997).

This paper pushes the argument that Ammu's 'radical death' (the only means to get over the ethnic deadlock of the Syrian Christian family) is defined as a woman's unavoidable (or inevitable) fate in a patriarchal Oedipus setting, especially in an under-developed community. In a broader context, it is arguable that if a woman could seek 'liberation' or, in Žižekian terms, if "when we encounter ourselves, we encounter death" (Žižek, 1992). Hence, the discussion herein covers two fundamentally, mutually inclusive, paradoxical positions of postmodern humanity; first, that under-developed patriarchal society is 'a symptom' or a symbolic failure (a society which is incapable of acknowledging universal love and human bondages) and second, that the woman who desires or seeks liberation from the backward cultural deadlock encounters the inevitable horror of annihilation (self or otherwise).

\section{Articulating Ammu: the triad of the imaginary, symbolic and real}

It is possible to engage in a Lacanian articulation of Ammu's character in The God of Small Things based on the Lacanian triad, which relies on 'the signification of the phallus' (Miller, 1993). According to Lacan, the psyche and the social of a human being is defined and centered around the Imaginary, Symbolic and Real of a subject's need and desire for 'the other' and 'Big Other', leading to the notion of jouissance. In Ammu's contextual position and her relationship with Velutha, her desire for him in the absence of a husband not only satisfies her basic desires, but also symbolically satisfies (at least temporarily) the need for a 'father-figure' for her twins, who bond with Velutha so easily. Consider for example Ammu's feeling as she views her children play with Velutha:

"She was surprised at the extent of her daughter's physical ease with him. Surprised that her child seemed to have a sub-world that exclude her entirely. A tactile world of smiles and laughter that she, her mother, had no part in. Ammu recognized vaguely that her thoughts were shot with a delicate, purple tinge of envy...

The man standing in the shade of the rubber trees with coins of sunshine dancing on his body, holding her daughter in his arms, glanced up and caught Ammu's gaze. History was wrong-footed, caught off-guard...

In that brief moment, Velutha looked up and saw things that he hadn't seen before... he saw that Rahel's mother was a woman...

Ammu saw that he saw. She looked away. He did too. History's fiends returned to claim them. To rewrap them in its old, scarred pelt and drag them back to where they really lived. Where the Love Laws lay down who should be loved. And how. And how much.” (Roy, 1997)

This phallic attraction of 'the other' in what Ammu sees in Velutha can be accounted for as Lacan's Imaginary domain in two perspectives. First, it is essentially masculine, and becomes the basis for a more far reaching epistemology within the Lacanian discourse. Secondly, this idealisation of the body in its 'Mirror Stage' as the centre of control can then be rearticulated in 'the signification of the phallus' in the form of a phallus as that which controls signification (Homer, 2013). This in turn, causes the most famous Lacanian 'split' in the Symbolic Order; the latter made possible when Ammu realises and accepts the Name-of-the Father, which translates in the novel as the laws and restrictions that control both Ammu's desire for Velutha and the rules of communication that allows or bars her association with him. According to Lacan, the Symbolic is all about desire, and it is this very desire-object that generates an entire discourse on Ammu in The God of Small Things.

The recognition of the Name-of-the-Father Ammu experiences makes her return from the spasmodic delirium of sexual enjoyment to the real world full of inhibitions based on caste and class. Hence, the relationship which she has with Velutha is a narcissistic one; both for Velutha and herself, ending in destruction for both. In order to satisfy her desire, she creates a 
'demand' for him, and this demand in itself is Imaginary, for it mirrors a lack or loss, and thus is a mere fantasy image. For Lacan, this Imaginary and Symbolic ('desire' and 'demand' in other words) are inextricably linked, and this is what one sees through the character of Ammu and her relationship with Velutha.

What goes beyond the Lacanian symbolic discourse is that there is nothing but self-destruction which results for those who go beyond the symbolic triad, due to the absence of a 'Big Other' (Miller, 1993) to hold those who radically divert from the collective entity that governs society. The 'absence' in this sense, is the 'failure' of society's 'radical behaviour' of individuals who desire to negate their present situation and move towards modernity (Habermas, 2007).

This is the realisation that erupts in Ammu, whenever her social circumstances compels her to acknowledge the materiality of her existence, and this acknowledgement, as the character rightfully reveals, is usually perceived as traumatic, since it threatens the phallocentric symbolic order or her existing reality, although it dialectically drives Lacan's sense of jouissance.

The tragedy that befalls both Ammu and Velutha is primarily due to the failed presence of a new symbolic order that does not exist to support Ammu's and Velutha's radicalism. As a result, their efforts are nothing but narcissistic and end up as self-destructive acts. Not only does this propose that woman's position beyond the phallus is implausible in both its metaphorical and literal sense, but it also provides an explanation as to why Ammu's internalisation of her radical act makes her lose her mind. Hence, the desire internalised in a system that does not provide an alternative, is also detrimental.

In a Hegelian sense,

"the only full case of absolute recoil, of a thing emerging through its very loss, is thus that of the subject itself, as the outcome of its own impossibility. In this precise Hegelian sense, the subject is the truth of substance: the truth of every substantial thing is that it is the retroactive effect of its own loss. The subject as $\$$ does not pre-exist its loss, it emerges from its loss as a return to itself. When one reaches the absolute standpoint (in disalienation) what one sees is that not only is the subject cosubstantial with its loss (in the sense that it is always barred, curtailed), but that the subject is the loss." (Žižek, 2014)

This plunging of the soul into the depth of its abyss is possibly seen, if one needs to place it within Roy's fiction, as the Asian soul's recoil into its own self; destructive since it is an act upon itself, rather than going into the outside world. What is mirrored from this act of coiling back is how it is more detrimental to the self than its externalised impact on society. An evident example of this phenomenon in work is displayed in Ammu, the novel's center locus, at the moment of her death when she is completely alienated from the outer world and has recoiled within:

"That night in the lodge, Ammu sat up in the strange bed in the strange room in the strange town. She didn't know where she was, she recognized nothing around her. Only her fear was familiar. The faraway man inside her began to shout. This time the steely fist never loosened its grip. Shadows gathered like bats in the steep hollows near her collarbone" (Roy, 1997).

Asthma, entailing traits of psychological disturbance, becomes the 'faraway man' that ultimately engulfs Ammu's life. Yet, the disease also connotes the inner recoil into which Ammu succumbs, and absolute recoil which brings ruin to the soul. The personification of the 'faraway man' illuminates how the recoil is destructive for the individual.

\section{Deadlock Symptoms}

It is essential to highlight the symptoms in Roy's Ayemenem that are the actual reasons of the society's symbolic failure to 'absorb' its subjects. One of the elementary insights of psychoanalysis within the network of intersubjective relations is that everyone is identified with, pinned down to, a certain fantasy place in the other's symbolic structure. This basic insight runs in opposition to usual commonsense belief that fantasy figures are nothing but distorted, combined or otherwise concocted figures of their 'real' models of those one meets in true experience.

In Žižekian light, Ammu's attraction and subsequent relationship with Velutha, or even Baby Kochamma's flirting with Father Muligan happens insofar as they are able to identify their respective personas of attraction with a certain place in their symbolic fantasy space. Alternatively said, it is only insofar as Velutha and Father Muligan fill out a place pre-established in Ammu's and Baby Kochamma's dreams that this attraction happensthey fall in love with men insofar as their features coincide with their fantasy figure of a Man, the 'real father' in actuality, being a miserable individual obliged to sustain the burden of the Name-of-the-Father, never fully adequate to his symbolic mandate, and so forth (Žižek, 1992). 
The deadlock of this externalisation of internalised fantasy occurs when the externalised object-desire (i.e. Velutha and Father Muligan's characters) fails to support the subjects which externalise their desire (Ammu and Baby Kochamma), ultimately resolving into what Žižek calls the "paradox of self-destructive female curiosity" (Žižek, 1992). Eventually, the discourse hints to an ultimate conclusion that woman beyond phallus has an ignoble, self-nihilistic fate. To push the argument further, the death-drive which is so evident at the end of the novel and failure of most characters also highlights that the symbolic termination of the family is also a combined result of political-ethnic and religious limitations of Ayemenem society, which hinders a true progressive social evolution to the next stage. Hence, the resisting characters of Ammu, Velutha, Chacko and the twins who ultimately succumb to each other (mentally and even physically towards the end of the novel) are examples of the societal deadlock in which forward moving, convention-resisting human beings cannot qualitatively enhance their life situations by dialectically negating the present stage to supersede to a higher one, eventually reaching a 'radical death'. A good example is the twins who turn to themselves:

"Twenty-three years later, Rahel, dark woman in a yellow T-shirt, turns to Estha in the dark...

She moves her mouth.

Their beautiful mother's mouth.

Estha, sitting very straight, waiting to be arrested, takes his finger to it. To touch the words it makes...His hand is held and kissed.

They were strangers who had met in a chance encounter.

They had known each other before Life began.

There is very little that anyone could say to clarify what happened next. Nothing that (in Mammachi's book) would separate Sex from Love. Or Needs from Feelings....

But what was there to say?

Only that there were tears. Only that Quietness and Emptiness fitted together like stacked spoons... Only that once again they broke the Love Laws. That lay down who should be loved. And how. And how much" (Roy, 1997).

Theoretically, for a negation of the present and limited society to take place, its agents of change need insight and a proper understanding of the present situation, which is not phenomenally provided for in the context of The God of Small Things. The ultimatum being that Ammu, Velutha, Chacko, the twins, Baby Kochamma and even Margaret Kochamma (Chacko's foreign wife) face a limitation in the rationalisation of their existence. When Ammu's existence in the Ayemenem household is limited to the restrictions of convention during day-time and temporary relief during the night-long expeditions in the arms of her conventionally disapproved lover, there occurs a terrible constraint in her and the culture she breeds in, forming a dialectic synthesis in the progressive reaction to tradition and nature. This is the reason why Ammu has a fated symbolic death and succumbs to the limitations of society and tradition, rather than moving to a higher level of cognitive perception, which is brutally denied:

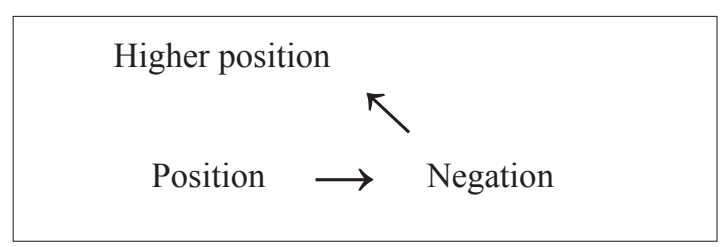

Figure 2: Dialectic synthesis in Progressive Reaction Source: Researcher's analogy

\section{An Analysis on the Whole}

All main characters in the novel in addition to the prime highlight on Ammu, i.e., Velutha, Chacko, the twins and even periphery-based caricatures of 'Indian' society, such as Father Mulligan are all schizoid individuals. Psychologically, the Schizoid Personality Disorder (SPD) is characterised as those who have problems in communicating with 'the other', except on a superficially required mundane level of requirement. Schizoids can only 'connect' as long as 'the other' does not demand a higher degree of emotional bondage. An illustrious example of this element of 'disconnectedness' is found in the relationship between Larry and his wife, Ammu:

"He held her as though she was a gift. Given to him in love. Something still and small. Unbearably precious.

But when they made love he was offended by her eyes. They behaved as though they belonged to someone else. Someone watching...

He was exasperated because he didn't know what that look meant. He put it somewhere between indifference and despair..." (Roy, 1997)

On the one hand, this theorem of 'connectivity' is true insofar as one observes the 'physical' relationship 
Ammu has with Velutha. Ironically though, 'the other' that Ammu sees in Velutha is not her emancipated, reassured, desired and mutually complementary 'other', but a state of momentary 'dislocation' and the result is an 'attempt of connection' with yet another failed caricature of Indian society: Velutha. To use Holbrook's articulation this is "schizoid suicide" (Holbrook, 1971), in the sense that Ammu's temporary happiness in Velutha is insofar as much as "the false beliefs of a schizoid individual that death can be a pathway to rebirth" (Holbrook, 1971).

Yet, what needs to be understood is that these situational ambivalences or the post-colonial's so common 'dual identities' (Bhabha, 1994) that hinders Ammu and Velutha and even the twins to a state of selfannihilation is the absence of space for 'Indianness' to hold those who break free or seek change or liberation from tradition. In this light, one of the failures of Roy's work is her inability to present to the reader an optimistic solution in the notion of 'Indianness' that could 'liberate' the said characters from their symbolic deadlock. In this sense, Roy's work is definitely a work of 'Small Things' insofar as it concentrates on parts, fragments and caricatures of 'Indianness', failing to address the social fabric as a whole.

The symbolic deadlock presented above is also the reason for Ammu, Baby Kochamma, Chacko, Margaret Kochamma and the twins to be victims of a system that does not develop to a stage where a complete change in the social and cultural life of the individuals was expected. The fact that Chacko banishes Ammu from the Ayemenem household, her only place of existence (radically or otherwise) is the final verdict of this proposition of failure.

A Frantz Fanonian articulation of this 'deadlock' and annihilation of characters in Roy's novel would possibly point the finger at post-colonial's "dependency complex" (Fanon, 2008), where subjects in concern are deliberately withheld from liberation and standing on their own, due to their psychological and possibly deliberate dependence on the Indian traumatic and claustrophobic social fabric of caste, which limits their breakthrough. In other words, the failure of the characters is their very dependency on an already failed caste system, which is the novel's (and Roy's) tragedy. As an author, one could almost state that Roy merely suffices to present this tragic enclosure of Indian fragments in society, but does not posit a solution, because there is almost 'no escape' from this interconnectedness to 'Indianness' which ironically has no place for 'misfits' such as Ammu, Velutha, Chacko and the twins.
A broader cultural hegemonic approach trailing from Gramsci (1992), later taken up specifically by Spivak (1995) is the very question whether the subaltern, with his/her liminalities could actually speak. Ammu's and Velutha's inability to 'speak' and make themselves heard, and thus receive existence in Kerala and 'exist' in Roy's plot reassures that the subaltern's voice is trapped, encompassing not only their lives, but that also of Chacko and the twins, who only could have a dialogue in isolation, within themselves; the very "organic-ness" (Chakrabarty, 2007; Žižek, 2011) in the 'Indian' community in which they live in being their own oppressor. Once again, the trajected weakness of what is often taken for granted as 'Indianness'; the dilemma in society being its inherent belief that organic entities equate the universal whole, which is in itself entrapment.

This dialectic of 'essentials of Indianness' versus the many " 'Indias' even in one India" (Chakraborty, 2009) that Chakraborty boldly explores and ventures into discourse in relation to Indian fiction, is the death (symbolic and otherwise) of the characters which are very much part of India in Roy's novel as well, i.e., Ammu, Velutha, Chako, Baby Kochamma and the twins. What one needs to question, ultimately, is this 'Big Other' (Miller, 1993) and its inevitable destruction.

In an interesting European outlook on 'third-world literature' Jameson (1986) significantly highlights that one of the primary problems in the said class of literature itself and within the characterisation of such is that the subject is only engaged in the Real in so much as it is part of the larger political, social and cultural context. In other words, the libidinal sphere is very much not a concentrated and isolated personal and private dimension that can be expressed within the contours of itself; rather it is very much inter-related and a mirror of the public. This allegorical representation of the third-world cultural productions, which posits its literature and characters in novels in a 'radical difference', though it validates signature features of the third-world subject and gives it due place, is itself deadlock that ends up in nothing but destruction- both for the characters as well as from the point of writers who then seemingly cannot escape from the trenches and suggest a way out.

Hence, as Jameson (1986) rightly highlights, the third-world "cultural intellectual...is also a political militant". For example, Chacko and his communist propagations within Roy's narrative is a symbolic failure in this light, both personal and in the political public, and again halt in a symbolic deadlock. Even his crosscultural wife and let alone the child (Sophie Mol) do not survive within the institution of family, suggestive that 
the first-world and third-world cannot link or relate to each other.

This brings us to a more fundamental issue that Jameson makes us aware of in terms of the notion of universalism versus radical difference. One could not but agree with Jameson when he says that once the cultures which highlight their radical difference (in this case the Syrian Christian ethnic minority in Indian Ayemenem), it "is susceptible to appropriation by that strategy of otherness...called "orientalism" " (Jameson, 1986). The cultural patterns that emerge from such groups, Jameson states, are reactions and "solutions to a dilemma, then become part of the new problem" (Jameson, 1986); the new problem intuitively being the problem of universality.

The claims made by Jameson brings us to the same conclusions that this paper has been instigating so far; that the cultural patterns displayed in the Syrian Christian culture depicted in Roy's fiction by the radical different community representing Ammu, Chacko the twins, etc., end up destructive, both when externalised or internalised. Hence, Ammu's break out with Velutha, and Chacko's marriage to Margaret, both examples of solutions to a 'way out', become part of a new problem: the problem of universalism within the Indian nationalistic discourse.

\section{CONCLUSION}

The discussion of the present research directs us to the fact that what is most highlighted in The God of Small Things is that woman is caught in a fundamental, paradoxical deadlock between the symbolic order defined by the backward patriarchy and her drive for liberation. Her instinctual demand for universal love could actually free 'man' (the masculine world order) and the world constructed by him. Yet, the paranoia of the patriarchy that liberates her finally destines nothing for her, but a permanent termination of her own existence. Hence, it is possible to conclude that the internalisation of fantasy in the Syrian Christian community in the novel is a patriarchal symptom of temporal survival, but the real liberation always rests in a 'universal form of radicalisation of desire' as shown by Ammu's character.

In more general terms, taken out of the context of Roy's fiction, the backward patriarchy exemplified in Roy's novel is the very phenomenon that restricts progress of society in postcolonial contexts such as Sri Lanka, where the female subject is often caught in a paradoxical symbolic deadlock surrounded by imaginary bonds of caste, class, religion and ethnicity. It is possible to conclude that if society needs to progress morally and socially, there needs to be a universal emancipation from this situation, wherein a woman beyond phallus would be possible, provided there is space for a new symbolic order known to all by democratic, voluntary means. This in turn would help postcolonial societies assert what Habermas' theory of social evolution highlighted as "progressive state of social change" (Owen, 2012), which would provide liberation for all across boundaries of sex, class, caste and any other manacles.

\section{END NOTES}

1. In this part of the world, the paternal signifier is often constructed on values borrowed from some imaginary tradition or pre-history. Hence, in moralizing human nature for better tomorrow, Habermas (2007) suggests "detraditionalization of the life world is an important aspect of societal modernization".

2. 'Radical Death' is a kind of annihilation or a 'wiping out' of everything including one's own existence as a symbolic gesture to show the limit of the symbolic community to which one belongs (Žižek, 1992).

\section{REFERENCES}

Ahmad, A. (1997) Postcolonial Theory and the 'Post-' Condition, The Socialist Register, pp: 353-381.

Ashcroft, B. Griffiths, G. \& Tiffin, H. (eds.) (1995) The PostColonial Studies Reader, London: Routledge.

Bhabha, H. K. (1994) The Location of Culture, London and New York: Routledge.

Bishop, R. S. (1992) Multicultural literature for children: Making informed choices, In Harris, V. (ed) Teaching multicultural literature in grades $K-8$, pp: 37-54, Norwood: Christopher-Gordon.

Chakrabarty, D. (2007) Provincializing Europe: Postcolonial Thought and Historical Difference, New Jersey: Princeton University Press.

Chakraborty, B. (2009) The Essentials of Indianness: Tolerance and Sacrifice in Indian Partition Fiction in English and in English Translation, Rupkatha Journal on Interdisciplinary Studies in Humanities, 1(1), pp: 3-32.

DOI: https://doi.org/10.21659/rupkatha.v1n1.01

Fanon, F. (1963) The Wretched of the Earth (trans. Constance Farriongton), New York: Grove Press.

Fanon, F. (2008) Black Skin White Masks, London: Pluto Press.

Flynn, T., LaMotte, A., Jordin, M. M., Stevenson, C. and Palma, C. (2009) 'Arundhati Roy' Voices from the Gaps, Minneapolis: University of Minnesota. 
Fuller, C. J. (1976) Kerala Christians and the Caste System, Man, 11(1), pp: 53-70.

DOI: https://doi.org/10.2307/2800388

Gramsci, A. (1992) Prison Notebooks, New York: Columbia University Press.

Habermas, J. (2007) The Future of Human Nature, London: Polity.

Holbrook, D. (1971) Human Hope and the Death Instinct: An Exploration of Psychoanalytic Theories of Human Nature and their Implications for Culture and Education, Oxford: Pergamon Press.

Homer, S. (2013) Jacques Lacan, London: Routledge.

Jameson, F. (1986) Third-World Literature in the Era of Multinational Capitalism, Social Text, 15, pp: 65-88.

DOI: https://doi.org/10.2307/466493

Jameson, F. (1991) Postmodernism or the Cultural Logic of Late Capitalism, Durham: Duke University Press.

John, J. (2007) Lifestyle of Kerala Syrian Christians. [Online] Available from: http://www.nasrani.net/2008/04/15/lifestyleof-kerala-syrian-christians [Accessed: $19^{\text {th }}$ January 2017]

Miller, J. (ed.) (1993) The Seminar of Jacques Lacan. Book III: The Psychoses, 1955-1956, New York: W.W. Norton and Company.

Nandy, A. (1983) The Intimate Enemy: Loss and Recovery of Self under Colonialism, Delhi: Oxford University Press.

Owen, D. S. (2012) Between Reason and History: Habermas and the Idea of Progress, New York: State University of New York Press.
Roy, A. (1997) The God of Small Things, New Delhi: IndiaInk.

Roy, A. (2001) Power Politics, Boston: South End Press.

Roy, A. (2005) An Ordinary Person's Guide to Empire, London: Penguin Books.

Roy, A. (2004) An Ordinary Person's Guide to Empire, Cambridge: South End Press.

Spivak, G. C. (1995) Can the Subaltern Speak?, In Ashcroft, B., Griffiths, G. and Tiffin, H. (eds.) The Post-colonial Studies Reader, London: Routledge, pp: 24-29.

Sydney Peace Foundation. (2017 \& 2004) Arundhati Roy [Online] Available from: http://sydneypeacefoundation.org. au/peace-prize-recipients/2004-arundhati-roy [Accessed: $22^{\text {nd }}$ January 2017].

Thompson, M. G. (2005) Phenomenology of intersubjectivity: A historical overview of the concept and its clinical implications, In: J. Mills (ed.) Relational and Intersubjective Perspectives in Psychoanalysis: A Critique, pp: 35-70, London: Jason Aronson.

Varghese, K. G. (2004) Writing Family Histories: Identity Construction among Syrian Christians, Economic and Political Weekly, 39(9), pp: 897-900.

Žižek, S. (1994) Metastates of Enjoyment, pp: 160-161, London: Verso.

Žižek, S. (1992) Enjoy Your Symptom!, New York: Routledge.

Žižek, S. (2011) Living in End Times, London: Verso.

Žižek, S. (2014) Absolute Recoil, pp: 98, London: Verso.

Žižek, S. (2013) Love as a Political Category [Online] Available from: https://www.youtube.com/watch? $\mathrm{v}=\mathrm{b} 44 \mathrm{IhiCuNw} 4$ [Accessed: 20 $0^{\text {th }}$ January 2017] 